\title{
Pengaruh Lokasi, Kelengkapan Produk, Dan Kualitas Pelayanan Terhadap Keputusan Pembelian Pada Alfamart Blahkiuh Di Kabupaten Badung
}

\author{
Ni Kadek Dewi Susanti ${ }^{1}$ \\ Putu Herny Susanti ${ }^{2}$ \\ Gusti Alit Suputra ${ }^{3}$ \\ ${ }^{1,2,3}$ Fakultas Ekonomi, Bisnis, dan pariwisata Universitas Hindu Indonesia \\ Email : dewisusanti116@gmail.com
}

\begin{tabular}{|l|l|l|}
\hline Diterima: 8 Desember 2020 & Direvisi: 13 Desember 2020 & Disetujui:16 Desember 2020 \\
\hline
\end{tabular}

\begin{abstract}
Purchasing decision is a process of integrating which is combined to evaluate two or more alternative behaviors and select one of them. The purpose of this study was to determine the effect of location, product completeness and service quality on purchasing decisions of Alfamart Belahkiuh in Badung Regency. This research was conducted at Alfamart Belahkiuh at Jalan Ciung Wanara, Br. Delod Pasar, Ex. Belahkiuh, Kec. Abiansemal, Kab. Badung. Questionnaires that have been tested for validity and reliability were given to respondents. The number of respondents taken was 99 respondents using the Accidental sampling method. Data collection was carried out through observation, interviews, documentation, literature study and questionnaires. The data analysis technique used is multiple linear regression analysis, determination test, $t$ test (partial regression), and $F$ test (simultaneous regression). Based on the results of the analysis, it was found that location had a positive and significant effect on purchasing decisions at Alfamart Blahkiuh in Badung. Product completeness has a positive and significant effect on purchasing decisions at Alfamart Blahkiuh in Badung. Service Quality has a positive and significant effect on Purchasing Decisions at Alfamart Blahkiuh in Badung. Location, Product Completeness and Service Quality have a positive and significant effect on Purchasing Decisions at Alfamart Blahkiuh in Badung.
\end{abstract}

Keywords: location, product completeness, and service quality

\begin{abstract}
ABSTRAK
Keputusan pembelian adalah proses pengintegrasian yang dikombinasikan untuk mengevaluasi dua atau lebih perilaku alternatif dan memilih salah satu di antaranya. Tujuan penelitian ini adalah untuk mengetahui pengaruh lokasi, kelengkapan produk dan kualitas pelayanan terhadap keputusan pembelian Alfamart Belahkiuh di Kabupaten Badung. Penelitian ini dilakukan pada Alfamart Belahkiuh di Jalan Ciung Wanara, Br. Delod Pasar, Kel. Belahkiuh, Kec. Abiansemal, Kab. Badung.Kuesioner yang sudah diuji Validitas dan Reabilitasnya diberikan kepada Responden Jumlah responden yang diambil sebanyak 99 responden metode Accidental sampling. Pengumpulan data dilakukan melalui observasi, wawancara, dokumentasi, studi pustaka dan kuesioner. Teknik analisis data yang digunakan adalah analisis regresi linier berganda, uji determinasi, uji t (regresi parsial), dan uji $\mathrm{F}$ (regresi simultan). Berdasarkan hasil analisis ditemukan bahwa Lokasi berpengaruh positif dan signifikan terhadap Keputusan Pembelian pada Alfamart Blahkiuh di Badung. Kelengkapan Produk berpengaruh positif dan signifikan terhadap Keputusan Pembelian pada Alfamart Blahkiuh di Badung. Kualitas Pelayanan berpengaruh positif dan signifikan terhadap Keputusan Pembelian pada Alfamart Blahkiuh di Badung.Lokasi, Kelengkapan Produk dan Kualitas Pelayanan berpengaruh positif dan signifikan terhadap Keputusan Pembelian pada Alfamart Blahkiuh di Badung.
\end{abstract}


Kata kunci : lokasi, kelengkapan produk, dan kualitas pelayanan

\section{PENDAHULUAN}

Alfamart merupakan usaha yang bergerak di bidang ritel. Hingga saat ini Alfamart masih dipilih konsumen sebagai pilihan tempat berbelanja. Perilaku konsumen yang akan berbelanja tentunya akan dipengaruhi oleh banyak faktor dalam menentukan keputusan pembelian. Salah satu cara yang dapat dilakukan perusahaan untuk membuat stretagi pemasaran yang tepat adalah dengan memiliki pengetahuan mengenai perilaku konsumen dan lingkungannya, khususnya terkait dengan bagaimana konsumen mengambil keputusan pembelian dan faktor-faktor yang mempengaruhi. Peter dan Olson (2012:162) menyatakan keputusan pembelian adalah proses pengintegrasian yang dikombinasikan untuk mengevaluasi dua atau lebih perilaku alternatif dan memilih salah satu di antaranya, sedangkan Winardi (2010:200) menyatakan keputusan pembelian konsumen merupakan titik suatu pembelian dari proses evaluasi.

Ada beberapa faktor yang digunakan untuk mengetahui keputusan pembelian konsumen adalah lokasi, kelengkapan produk dan kualitas Pelayanan. Menurut (Utami, 2012) Lokasi merupakan struktur fisik dari sebuah usaha yang merupakan komponen utama yang terlihat dalam membentuk kesan sebuah usaha yang dilakukan perusahaan dalam melakukan penempatan usahanya dan kegiatan dalam menyediakan saluran pelayanan yang dibutuhkan oleh konsumen. Selain Lokasi, hal yang perlu diperhatikan agar dapat menarik konsumen adalah Kelengkapan produk. Produk adalah segala sesuatu yang dapat ditawarkan ke suatu pasar untuk memenuhi kebutuhan atau keinginan. Konsumen akan melihat suatu produk berdasarkan pada karakteristik atau ciri, atau atribut produk dari produk tersebut (Lupiyoadi, 2013). Selain lokasi, kelengkapan produk kualitas pelayanan juga mempengaruhi keputusan pembelian, dengan pelayanan yang baik membuat masyarakat akan terus berbelanja di di Alfamart Blahkiuh. Olsen dan Wyckoff dalam buku Yamit (2010:22) mengatakan kualitas pelayanan adalah sekelompok manfaat yang berdaya guna baik secara eksplisit maupun implisit atas kemudahan untuk mendapatkan barang maupun jasa pelayanan. 1

Omzet penjualan Toko Alfamart Blahkiuh mengalami Fluktasi pada penjualan periode Januari sampai Desember 2018. Presentase/realisasi dari target yang ditentukan pada bulan April menunjukan presentase yang paling rendah dengan target penjualan sebesar Rp.349,747,783 namun hanya bisa terrealisasi sebesar Rp.313,665,901,- dengan presentase 90 persen hal ini terjadi karena pada bulan april terdapat program belanja dan juga promo yang kurang menarik minat konsumen untuk berbelanja dan sebagian besar nominal belanja tiap konsumen, lebih rendah dibandingkan dengan bulan sebelumnya. Hal ini mengindikasikan adanya penurunan 
minat beli konsumen di Alfamart blahkiuh. Selanjutnya pencapaian tertinggi terjadi pada bulan Desember dengan target penjualan sebesar Rp. 349,747,783,- namun bisa terrealisasi penjualan sebesar Rp.398,390,315,- dengan presentase 114 persen. Hal ini di karenakan adanya hari raya besar umat nasrani, hari raya Natal dan juga perayaan akhir tahun.

Penelitian ini bertujuan untuk (1) mengetahui pengaruh lokasi terhadap keputusan pembelian, (2) mengetahui pengaruh kelengkapan produk terhadsap keputusan pembelian, (3) mengetahui pengaruh kualitas pelayanan terhadap keputusan pembelian, dan (4) mengetahui pengaruh lokasi, kelengkapan produk, kualitas pelayanan terhadap keputusan pembelian di Alfamart Belahkiuh.

\section{TELAAH LITERATUR DAN HIPOTESIS}

Lokasi merupakan struktur fisik dari sebuah usaha yang merupakan komponen utama yang terlihat dalam membentuk kesan sebuah usaha yang dilakukan perusahaan dalam melakukan penempatan usahanya dan kegiatan dalam menyediakan saluran pelayanan yang dibutuhkan oleh konsumen (Utami, 2012) Menurut Heizer (2015:202) lokasi adalah pendorong biaya dan pendapatan, maka lokasi seringkali memiliki kekuasanaan untuk membuat strategi bisnis perusahaan. Menurut Kotler dan Amstrong (2012) lokasi adalah kegiatan perusahaan yang membuat produk tersedia bagi sasaran.

\section{Kelengkapan Produk}

Kelengkapan produk adalah kelengkapan produk yang menyangkut kedalaman, luas, dan kualitas produk yang ditawarkan juga ketersediaan produk tersebut setiap saat ditoko (Utami, 2012).Penyediaan kelengkapan produk (product assortment) yang baik tidak hanya akan menarik minat tetapi dapat mempengaruhi keputusan konsumen untuk berbelanja. Konsumen akan melihat suatu produk berdasarkan pada karakteristik atau ciri, atau atribut produk dari produk tersebut. Kelengkapan produk adalah kelengkapan produk yang menyangkut kedalaman, luas, dan kualitas produk yang ditawarkan juga ketersediaan produk tersebut setiap saat ditoko (Utami, 2010).

\section{Kualitas Pelayanan}

Kualitas pelayanan merupakan evaluasi konsumen tentang kesempurnaan kinerja layanan. Kualitas pelayanan bersifat dinamis yaitu berubah menurut tuntunan pelanggan (Fure, 2013) Olsen dan Wyckoff dalam buku Yamit (2010:22) mengatakan kualitas pelayanan adalah sekelompok manfaat yang berdaya guna baik secara eksplisit maupun implisit atas kemudahan untuk mendapatkan barang maupun jasa pelayanan. Kotler dan Keller (2012:83) mendefinisikan pelayanan adalah setiap tindakan atau kegiatan yang dapat ditawarkan oleh suatu pihak kepada 
pihak lain, yang pada dasarnya tidak berwujud dan tidak mengakibatkan kepemilikan apapun. Menurut Parasuraman et al (1988) kualitas pelayanan terdiri atas aspek bukti fisik, kehandalan, daya tanggap, jaminan, dan empati.

\section{Keputusan Pembelian}

Winardi (2010:200) menyatakan keputusan pembelian konsumen merupakan titik suatu pembelian dari proses evaluasi. Sedangkan Peter dan Olson (2009:162) menyatakan keputusan pembelian adalah proses pengintegrasian yang dikombinasikan untuk mengevaluasi dua atau lebih perilaku alternatif dan memilih salah satu di antaranya. Proses keputusan pembelian merupakan suatu perilaku konsumen untuk menentukan suatu proses pengembangan keputusan dalam membeli suatu produk. Proses tersebut merupakan sebuah penyelesaian masalah harga yang terdiri dari lima tahap (Kotler, 2010).

\section{Hipotesis}

Berdasarkan rumusan masalah tentang pengaruh lokasi, kelengkapan produk kualitas pelayanan terhadap keputusan pembelian dirumuskan hipotesis sebagai berikut :

$\mathrm{H} 1=$ Diduga Lokasi berpengaruh positif dan signifikan terhadap keputusan pembelian pada Alfamart Blahkiuh

H2 = Diduga kelengkapan Produk berpengaruh positif dan signifikan terhadap keputusan pembelian pada Alfamart Blahkiuh

H3 = Diduga kualitas pelayanan berpengaruh positif dan signifikan terhadap keputusan pembelian pada Alfamart Blahkiuh

H4 = Diduga Lokasi, Kelengkapan Produk dan kualitas pelayanan berpengaruh positif dan signifikan terhadap keputusan pembelian pada Alfamart Blahkiuh.

\section{METODE PENELITIAN}

\section{Desain Penelitian}

Kerangka pemikiran menggambarkan hubungan dari variabel independen, dalam hal ini adalah pengaruh lokasi (X1), kelengkapan produk (X2), kualitas pelayanan (X3), terhadap variabel dependen yaitu keputusan Pembelian (Y) yang dilakukan oleh konsumen di Alfamart Blahkiuh. 


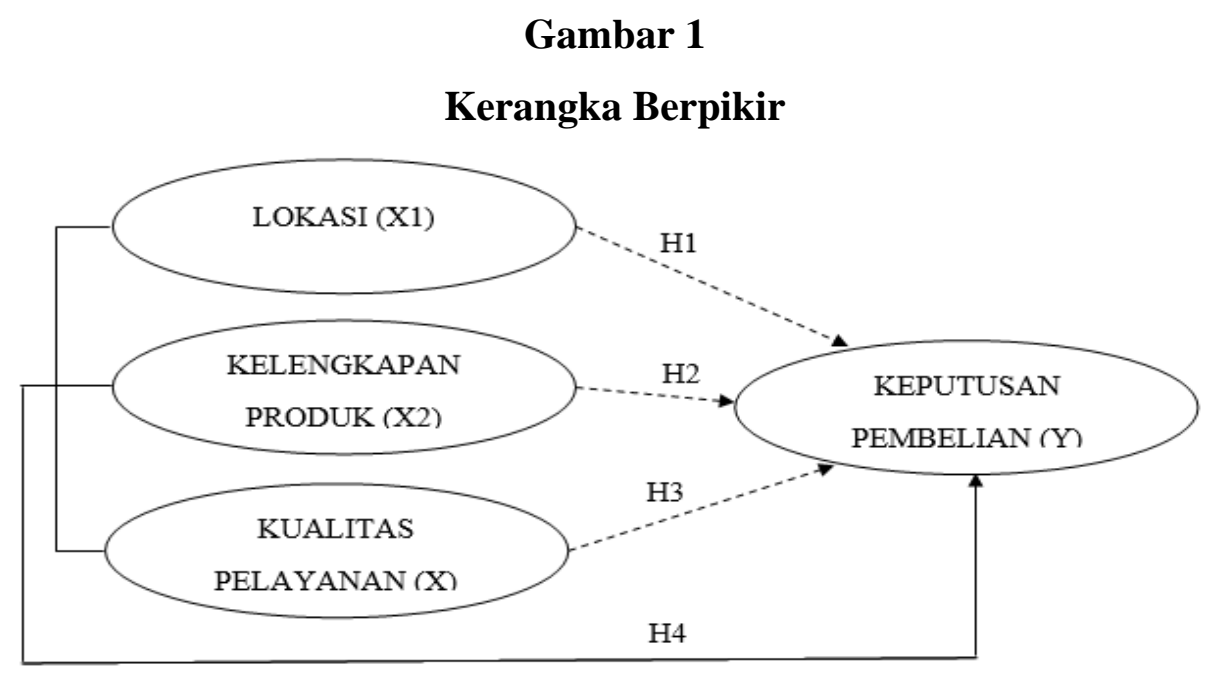

\section{Populasi dan Sampel}

Berdasarkan Data yang didapat Tahun 2018 dengan menggunakan data pengunjung bulan ke 12 di Tahun 2018 (10.678) Struk belanja yang dicetak. Dengan asumsi 1 struk sama dengan 1 orang konsumen, maka populasi dalam penelitian ini sebanyak 10.678 pelanggan, dan dengan menggunakan Rumus Slovin maka diperoleh sampel sebanyak 99 orang responden. Teknik penentuan sampel menggunakan accidental sampling.

\section{Metode Pengumpulan Data}

Pengumpulan data dalam penelitian ini dilakukan dnegan menggunakan metode observasi, wawancara, dokumentasi, studi pustaka, dan kuisioner. Untuk mengetahui tanggapan responden terhadap variabel yang diteliti digunakan Skala Likert dengan lima pilihan jawaban yaitu sangat tidak setuju diberi nilai 1 , tidak setuju diberi nilai 2 , ragu-ragu diberi nilai 3 , setuju diberi nilai 4, dan sangat setuju diberi nilai 5.

\section{Analisis Data}

1 Uji instrumen penelitian, dilakukan dengan menggunakan uji validitas yaitu untuk mengukur sah atau valid tidaknya suatu kuesioner, dan uji reliabilitas adalah tingkat keandalan kuesioner. Kuesioner yang reliabel adalah kuesioner yang apabila dicobakan secara berulangulang kepada kelompok yang sama akan menghasilkan data yang sama.

2 Uji asumsi klasik, yang terdiri atas uji normalitas, uji multikolinearitas, dan uji heteroskedastisitas. 
3. Analisis regresi linear berganda. Dalam analisa ini yang ingin diperoleh adalah ada tidaknya hubungan sebab akibat antara variabel-variabel tersebut, variabel yang menyebabkan terjadinya perubahan terhadap variabel lain disebut variabel independen, sedangkan variabel yang terkena pengaruh variabel lainnya disebut variabel dependen.

\section{HASIL DAN PEMBAHASAN}

\section{Uji Instrumen Penelitian}

Berdasarkan Tabel 1, diketahui bahwa seluruh pernyataan memiliki koefisien korelasi yang lebih besar dari 0,30. Jadi dapat disimpulkan bahwa seluruh indikator telah memenuhi syarat validitas data.

Tabel 1. Hasil Uji Validitas Variabel

\begin{tabular}{|c|c|c|c|}
\hline \multicolumn{4}{|c|}{ Variabel Keputusan Pembelian } \\
\hline No & Indikator & Koefisien Korelasi & Keterangan \\
\hline 1 & Y.1 & 0,773 & Valid \\
\hline 2 & Y.2 & 0,795 & Valid \\
\hline 3 & Y.3 & 0,603 & Valid \\
\hline 4 & Y.4 & 0,688 & Valid \\
\hline 5 & Y.5 & 0,854 & Valid \\
\hline 6 & Y.6 & 0,895 & Valid \\
\hline 7 & Y.7 & 0,864 & Valid \\
\hline 8 & Y.8 & 0,901 & Valid \\
\hline 9 & Y.9 & 0,907 & Valid \\
\hline 10 & Y.10 & 0,869 & Valid \\
\hline 11 & Y.11 & 0,894 & Valid \\
\hline 12 & Y.12 & 0,706 & Valid \\
\hline \multicolumn{4}{|c|}{ Variabel Lokasi } \\
\hline No & Indikator & Koefisien Korelasi & Keterangan \\
\hline 1 & $\mathrm{X} 1.1$ & 0,884 & Valid \\
\hline 2 & $\mathrm{X} 1.2$ & 0,751 & Valid \\
\hline 3 & $\mathrm{X} 1.3$ & 0,923 & Valid \\
\hline 4 & $\mathrm{X} 1.4$ & 0,911 & Valid \\
\hline 5 & $\mathrm{X} 1.5$ & 0,889 & Valid \\
\hline 6 & X1.6 & 0,932 & Valid \\
\hline 7 & X1.7 & 0,568 & Valid \\
\hline 8 & $\mathrm{X} 1.8$ & 0,899 & Valid \\
\hline 9 & X1.9 & 0,723 & Valid \\
\hline 10 & $\mathrm{X} 1.10$ & 0,911 & Valid \\
\hline
\end{tabular}

Variabel Kelengkapan Produk

No 


\begin{tabular}{cccc}
\hline 1 & X2.1 & 0,893 & Valid \\
2 & X2.2 & 0,830 & Valid \\
3 & X2.3 & 0,719 & Valid \\
4 & X2.4 & 0,702 & Valid \\
5 & X2.5 & 0,742 & Valid \\
6 & X2.6 & 0,795 & Valid \\
7 & X2.7 & 0,620 & Valid \\
8 & X2.8 & 0,937 & Valid \\
Variabel Kualitas Pelayanan & & \\
No & Indikator & Koefisien Korelasi & Keterangan \\
1 & X3.1 & 0,617 & Valid \\
2 & X3.2 & 0,687 & Valid \\
3 & X3.3 & 0,613 & Valid \\
4 & X3.4 & 0,615 & Valid \\
5 & X3.5 & 0,612 & Valid \\
6 & X3.6 & 0,349 & Valid \\
7 & X3.7 & 0,758 & Valid \\
8 & X3.8 & 0,657 & Valid \\
9 & X3.9 & 0,412 & Valid \\
10 & X3.10 & 0,597 & Valid \\
\hline
\end{tabular}

Sumber : data diolah, 2020

Untuk mengukur reliabilitas dengan uji statistik cronbach alpha lebih besar dari 0,60. Hasil uji menunjukkan nilai cronbach alpha yang dapat dilihat pada Tabel 2. Berdasarkan Tabel 2, dapat dilihat bahwa semua variabel telah memenuhi syarat reliabilitas data.

Tabel 2.Hasil Uji Reliabilitas

\begin{tabular}{clcc}
\hline No & Variabel & Cronbach Alpha & Keterangan \\
\hline 1 & Keputusan Pembelian & 0,954 & Reliabel \\
2 & Lokasi & 0,953 & Reliabel \\
3 & Kelengkapan Produk & 0,906 & Reliabel \\
4 & Kualitas Pelayanan & 0,791 & Reliabel \\
\hline
\end{tabular}

Sumber : Data Diolah, 2020

\section{Karakteristik Responden}

Dari Tabel 3 dapat dilihat bahwa responden dalam penelitian ini terbagi menjadi 2 yaitu laki-laki sebanyak 57 orang $(57,58 \%)$ dan responden perempuan sebanyak 42 orang $(42,42 \%)$. 
Hal ini berarti sebagian besar responden pada Alfamart Blahkiuh di Kabupaten Badung adalah berjenis kelamin laki-laki.

Tabel 3. Karakteristik Responden Berdasarkan Jenis Kelamin

\begin{tabular}{lcc}
\hline \multicolumn{1}{c}{ Jenis Kelamin } & $\begin{array}{c}\text { Jumlah Responden } \\
\text { (Orang) }\end{array}$ & $\begin{array}{c}\text { Persentase } \\
(\boldsymbol{\%})\end{array}$ \\
\hline Laki-Laki & 57 & 57,58 \\
Perempuan & 42 & 42,42 \\
Jumlah & $\mathbf{9 9}$ & $\mathbf{1 0 0}$ \\
\hline
\end{tabular}

Sumber : data diolah, 2020

Pada Tabel 4, dapat dinyatakan bahwa responden yang terbanyak berusia 16-30 Tahun sebanyak 47 orang $(47,47 \%)$, dan jumlah terkecil adalah diatas 40 Tahun sebanyak 8 orang $(8,08 \%)$. Hal ini mengindikasikan bahwa konsumen pada Alfamart Blahkiuh cenderung lebih banyak berusia produktif/ usia yang sudah memiliki pekerjaan dan memiliki penghasilan.

\section{Tabel 4.Karakteristik Responden Berdasarkan Usia}

\begin{tabular}{lcc}
\multicolumn{1}{c}{ Usia } & $\begin{array}{c}\text { Jumlah Responden } \\
\text { (Orang) }\end{array}$ & $\begin{array}{c}\text { Persentase } \\
(\mathbf{\%})\end{array}$ \\
\hline <15 Tahun & 25 & 25,25 \\
16-30 Tahun & 47 & 47,47 \\
31-40 Tahun & 19 & 19,19 \\
>40 tahun & 8 & 8,08 \\
Jumlah & $\mathbf{9 9}$ & $\mathbf{1 0 0}$ \\
\hline
\end{tabular}

Sumber : data diolah, 2020

Pada Tabel 5, dapat dinyatakan bahwa responden yang terbanyak berpendidikan Sarjana sebanyak 37 orang $(37,37 \%)$, dan jumlah terkecil adalah berpendidikan SD sebanyak 9 orang (9,09\%). Hal ini mengindikasikan bahwa konsumen Pada Alfamart Blahkiuh di Badung lebih dominan berpendidikan Sarjana, dimana seluruh responden sudah memiliki tingkat pendidikan yang cukup tinggi.

Tabel 5. Karakteristik Responden Menurut Tingkat Pendidikan

\begin{tabular}{lcc}
\hline \multicolumn{1}{c}{ Tingkat Pendidikan } & $\begin{array}{c}\text { Jumlah } \\
\text { (Orang) }\end{array}$ & $\begin{array}{c}\text { Persentase } \\
(\boldsymbol{\%})\end{array}$ \\
\hline SD & 9 & 9,09 \\
SMP & 24 & 24,24 \\
SMA/SMK & 29 & 29,29 \\
Diploma/Sarjana & 37 & 37,37 \\
Total & $\mathbf{9 9}$ & $\mathbf{1 0 0}$ \\
\hline
\end{tabular}

Sumber : data diolah, 2020

Pada Tabel 6, dapat dinyatakan bahwa responden yang terbanyak berprofesi sebagai pelajar/mahasiswa sebanyak 51 orang $(51,52 \%)$ dan jumlah terkecil yaitu pegawai sebanyak 18 orang (18,18\%). Hal ini Mengindikasikan bahwa responden Pada Alfamart Blahkiuh di Badung lebih dominan berstatus pelajar dan mahasiswa.

Tabel 6. Karakteristik Responden Menurut Pekerjaan 


\begin{tabular}{lcc}
\hline \multicolumn{1}{c}{ Pekerjaan } & $\begin{array}{c}\text { Jumlah } \\
\text { (Orang) }\end{array}$ & $\begin{array}{c}\text { Persentase } \\
(\boldsymbol{\%})\end{array}$ \\
\hline Wiraswasta & 30 & 30,30 \\
Pelajar/Mahasiswa & 51 & 51,52 \\
Pegawai & 18 & 18,18 \\
Total & $\mathbf{9 9}$ & $\mathbf{1 0 0}$ \\
\hline
\end{tabular}

Sumber : data diolah, 2020

\section{Deskripsi Jawaban Responden}

Berdasarkan Tabel 7 dapat dilihat bahwa seluruh penilaian katagori seluruh pernyataan kuesioner termasuk dalam katagori sangat baik dengan skor rata-rata sebesar 4,63. Jawaban dengan nilai rata-rata tertinggi terdapat dalam pernyataan no 2 dengan nilai rata-rata sebesar 4,63 menyatakan bahwa Konsumen berbelanja di Toko Alfamart Blahkiuh karena produk yang di butuhkan tersedia disana. Sedangkan untuk nilai rata-rata jawaban terendah terdapat dalam pernyataan no 9 dengan skor rata-rata sebesar 4,17 dimana menyatakan bahwa Alfamart Blahkiuh memberikan berbagai promo membuat konsumen berbelanja dengan jumlah banyak. Hal ini menghindikasikan bahwa Alfamart Blahkiuh di Badung kurang memberikan berbagai promo yang menarik sehingga membuat konsumen tidak berbelanja dalam jumlah besar.

\section{Tabel 7. Kriteria dan Jawaban Penilaian Jawaban Kuesioner Variabel Keputusan} Pembelian

\begin{tabular}{|c|c|c|c|c|c|c|c|c|c|}
\hline \multirow{2}{*}{\multicolumn{2}{|c|}{ Pernyataan }} & \multicolumn{5}{|c|}{ Jawaban } & \multirow[t]{2}{*}{$\begin{array}{c}\text { Jumlah } \\
\text { Skor }\end{array}$} & \multirow{2}{*}{$\begin{array}{l}\text { Rata- } \\
\text { Rata } \\
\text { Skor }\end{array}$} & \multirow[t]{2}{*}{$\begin{array}{l}\text { Kategori } \\
\text { Penilaian }\end{array}$} \\
\hline & & 5 & 4 & 3 & 2 & 1 & & & \\
\hline 1 & $\begin{array}{l}\text { Konsumen berbelanja di Alfamart } \\
\text { Blahkiuh setelah mengetahui } \\
\text { kelengkapan produk yang dijual }\end{array}$ & 57 & 38 & 4 & 0 & 0 & 449 & 4,54 & $\begin{array}{c}\text { Sangat } \\
\text { Baik }\end{array}$ \\
\hline 2 & $\begin{array}{l}\text { Konsumen berbelanja di Toko } \\
\text { Alfamart Blahkiuh karena produk } \\
\text { yang di butuhkan tersedia disana }\end{array}$ & 69 & 23 & 7 & 0 & 0 & 458 & 4,63 & $\begin{array}{c}\text { Sangat } \\
\text { baik }\end{array}$ \\
\hline 3 & $\begin{array}{l}\text { Alfamart Blahkiuh memberi lebel } \\
\text { harga disetiap merek yang } \\
\text { berbeda dengan baik }\end{array}$ & 64 & 27 & 8 & 0 & 0 & 452 & 4,57 & $\begin{array}{c}\text { Sangat } \\
\text { Baik }\end{array}$ \\
\hline 4 & $\begin{array}{l}\text { Konsumen memilih berbelanja di } \\
\text { Toko Alfamart Blahkiuh karena } \\
\text { merek barang yang diinginkan } \\
\text { tersedia di toko }\end{array}$ & 58 & 32 & 9 & 0 & 0 & 445 & 4,49 & $\begin{array}{c}\text { Sangat } \\
\text { Baik }\end{array}$ \\
\hline 5 & $\begin{array}{l}\text { Konsumen berbelanja di Toko } \\
\text { Alfamart Blahkiuh setelah } \\
\text { konsumen medapatkan informasi } \\
\text { dari orang lain }\end{array}$ & 48 & 38 & 12 & 1 & 0 & 430 & 4,34 & $\begin{array}{c}\text { Sangat } \\
\text { Baik }\end{array}$ \\
\hline 6 & $\begin{array}{lrr}\text { Konsumen } & \text { memilih } & \text { Toko } \\
\text { Alfamart } & \text { Blahkiuh } & \text { sebagai } \\
\text { penyalur produk karena } & \text { memiliki } \\
\text { ketersediaan } & \text { produk } & \text { yang } \\
\text { memadai } & & \end{array}$ & 58 & 24 & 17 & 0 & 0 & 437 & 4,41 & $\begin{array}{c}\text { Sangat } \\
\text { baik }\end{array}$ \\
\hline 7 & $\begin{array}{l}\text { Konsumen berbelanja di Toko } \\
\text { Alfamart } \\
\text { kapanpunmereka inginkan karena } \\
\text { toko buka setiap hari }\end{array}$ & 58 & 23 & 17 & 1 & 0 & 435 & 4,39 & $\begin{array}{c}\text { Sangat } \\
\text { Baik }\end{array}$ \\
\hline
\end{tabular}




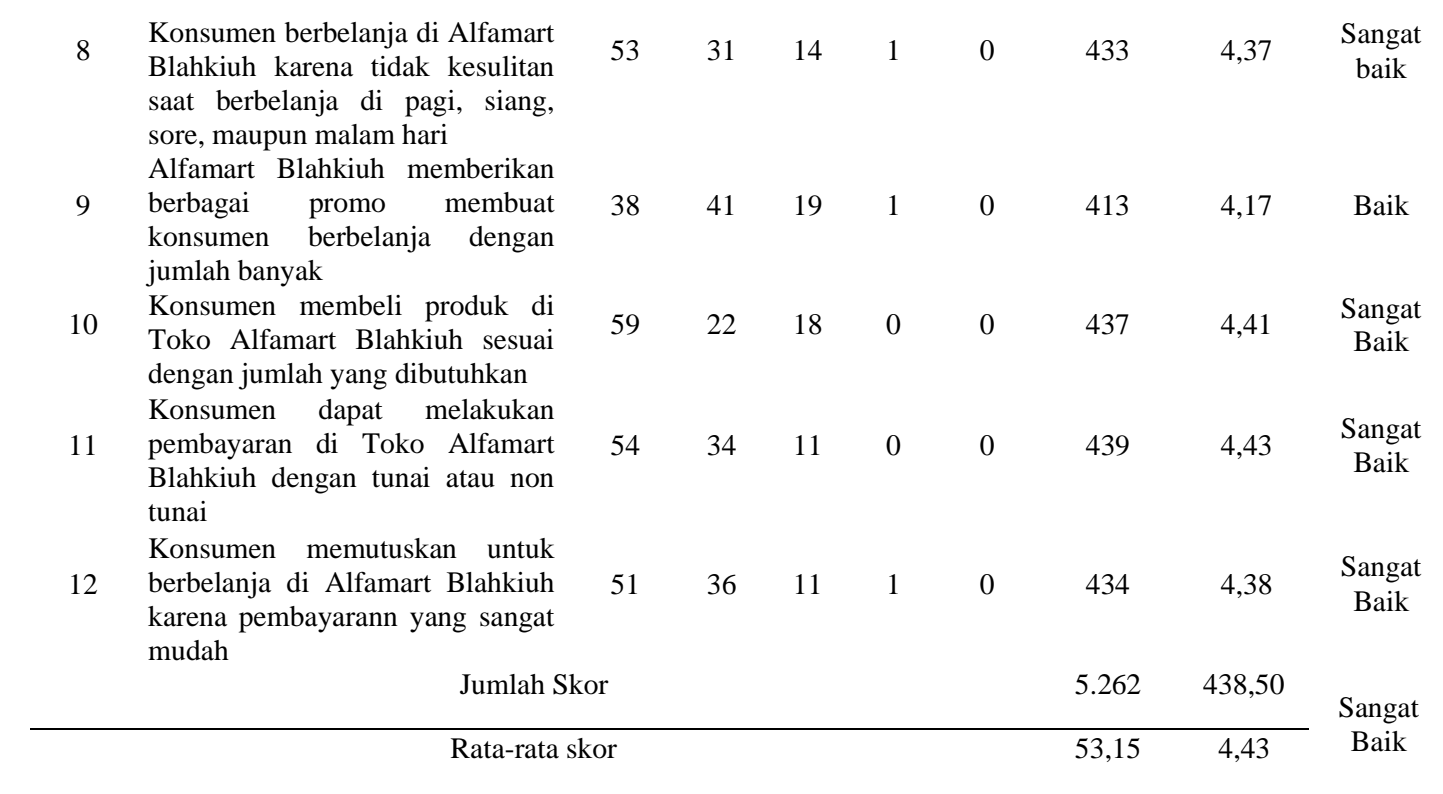

Sumber : data diolah, 2020

Berdasarkan Tabel 8, dapat dilihat bahwa seluruh penilaian katagori seluruh pernyataan kuesioner termasuk dalam katagori baik dengan rata-rata skor sebesar 4,08. Jawaban dengan nilai rata-rata tertinggi terdapat dalam pernyataan no 6 dengan nilai rata-rata sebesar 4,18 yang menyatakan bahwa Lokasi Toko Alfamart Blahkiuh verada dekat dengan pemungkiman pendidik. Sedangkan untuk nilai rata-rata jawaban terendah terdapat dalam pernyataan no 10 dengan nilai rata-rata sebesar 3,96 dimana menyatakan bahwa Alfamart Blahkiuh mudah dijangkau berbagai transportasi.

Tabel 8.Kriteria dan Jawaban Penilaian Jawaban Kuesioner Variabel Lokasi

\begin{tabular}{|c|c|c|c|c|c|c|c|c|c|}
\hline & \multirow{2}{*}{ Pernyataan } & \multicolumn{5}{|c|}{ Jawaban } & \multirow[t]{2}{*}{$\begin{array}{l}\text { Jumlah } \\
\text { Skor }\end{array}$} & \multirow{2}{*}{$\begin{array}{l}\text { Rata- } \\
\text { Rata } \\
\text { Skor }\end{array}$} & \multirow[t]{2}{*}{$\begin{array}{l}\text { Kategori } \\
\text { Penilaian }\end{array}$} \\
\hline & & 5 & 4 & 3 & 2 & 1 & & & \\
\hline 1 & $\begin{array}{lrr}\text { Akses menuju } & \text { Alfamart } \\
\text { Blahkiuh memiliki lokasi } \\
\text { yang strategis sehingga } \\
\text { mudah dijangkau }\end{array}$ & 32 & 46 & 20 & 1 & 0 & 406 & 4,10 & Baik \\
\hline 2 & $\begin{array}{l}\text { Toko Alfamart Blahkiuh } \\
\text { dekat dan terlihat jelas dari } \\
\text { jalan utama sehingga mudah } \\
\text { ditemukan }\end{array}$ & 29 & 50 & 20 & 0 & 0 & 405 & 4,09 & Baik \\
\hline 3 & $\begin{array}{l}\text { Lokasi Alfamart Blahkiuh } \\
\text { memiliki akses jalan yang } \\
\text { lancar dan terbebas dari } \\
\text { kemacetan }\end{array}$ & 36 & 44 & 18 & 1 & 0 & 412 & 4,16 & Baik \\
\hline 4 & $\begin{array}{l}\text { Kondisi jalan menuj lokasi } \\
\text { Alfamart Blahkiuh bagus } \\
\text { dan aman }\end{array}$ & 30 & 48 & 21 & 0 & 0 & 405 & 4,09 & Baik \\
\hline 5 & $\begin{array}{lll}\text { Lokasi } & \text { Toko } & \text { Alfamart } \\
\text { Blahkiuh } & \text { berada } & \text { di tengah }\end{array}$ & 29 & 48 & 22 & 0 & 0 & 403 & 4,07 & Baik \\
\hline
\end{tabular}




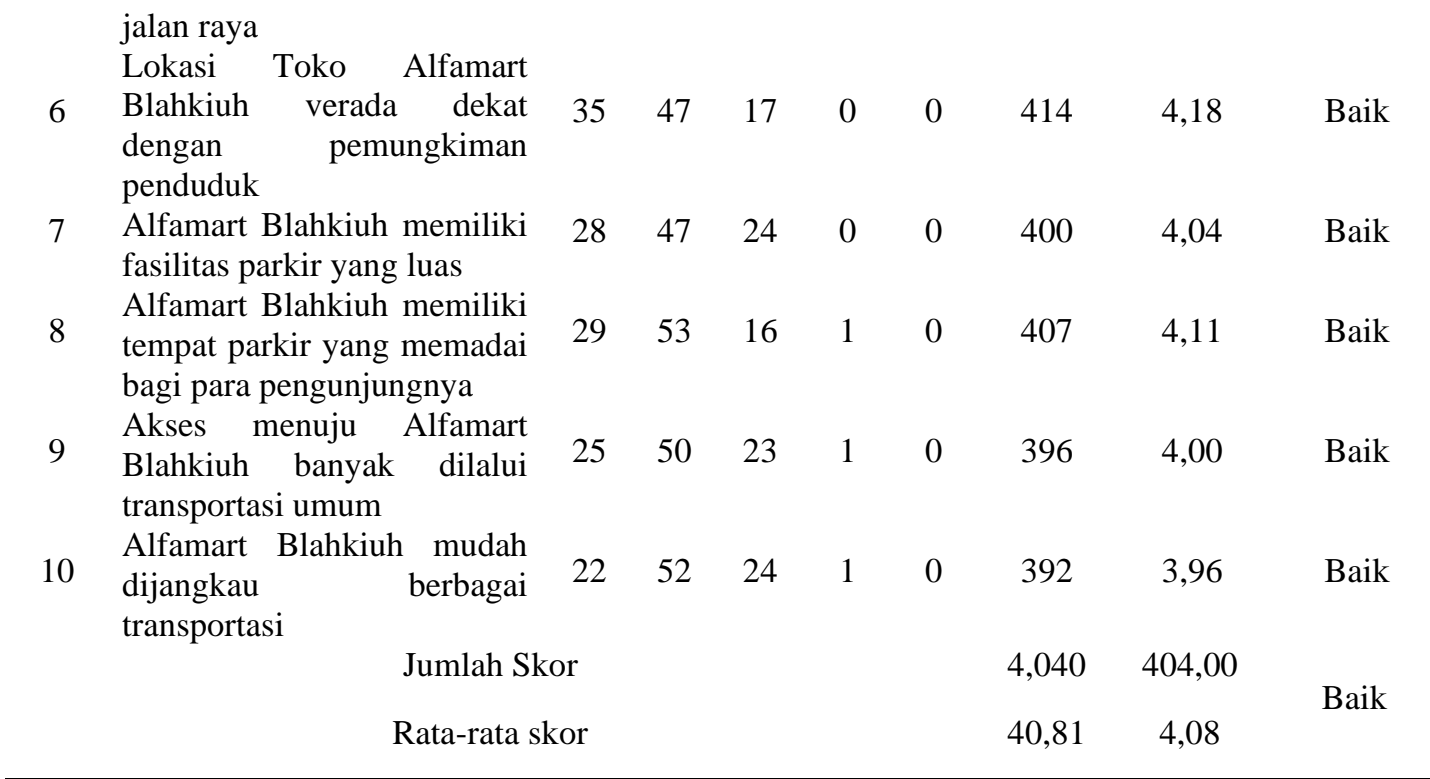

Sumber : data diolah, 2020

Berdasarkan Tabel 9 dapat dilihat bahwa seluruh penilaian katagori seluruh pernyataan kuesioner termasuk dalam katagori baik dengan skor rata-rata sebesar 4,06. Jawaban dengan nilai rata-rata tertinggi terdapat dalam pernyataan no 5 dengan nilai rata-rata sebesar 4,22 menyatakan bahwa Alfamart Blahkiuh menyediakan produk yang dibtuhkan oleh konsumen. Sedangkan untuk nilai rata-rata jawaban terendah terdapat dalam pernyataan no 2 dengan nilai rata-rata sebesar 3,85 dimana menyatakan bahwa Keragaman produk yang ditawarkan Alfamart Blahkiuh memiliki ciri khas sendiri dibanding Toko retail lain.

Tabel 9.Kriteria dan Jawaban Penilaian Jawaban Kuesioner Variabel Kelengkapan Produk

\begin{tabular}{|c|c|c|c|c|c|c|c|c|c|}
\hline \multirow{2}{*}{\multicolumn{2}{|c|}{ Pernyataan }} & \multicolumn{5}{|c|}{ Jawaban } & \multirow{2}{*}{$\begin{array}{l}\text { Jumlah } \\
\text { Skor }\end{array}$} & \multirow{2}{*}{$\begin{array}{l}\text { Rata- } \\
\text { Rata } \\
\text { Skor }\end{array}$} & \multirow{2}{*}{$\begin{array}{l}\text { Kategori } \\
\text { Penilaian }\end{array}$} \\
\hline & & 5 & 4 & 3 & 2 & 1 & & & \\
\hline & Barang yang ditawarkan & & & & & & & & \\
\hline 1 & $\begin{array}{l}\text { Alfamart Blahkiuh sesuai } \\
\text { dengan kebutuhan konsumen }\end{array}$ & 27 & 48 & 23 & 1 & 0 & 398 & 4,02 & Baik \\
\hline 2 & $\begin{array}{l}\text { Keragaman produk yang } \\
\text { ditawarkan Alfamart Blahkiuh } \\
\text { memiliki ciri khas sendiri di } \\
\text { sbanding Toko retail lain } \\
\text { Variasi produk yang dijual di }\end{array}$ & 15 & 54 & 30 & 0 & 0 & 381 & 3,85 & Baik \\
\hline 3 & $\begin{array}{l}\text { Alfamart Blahkiuh sangat } \\
\text { beragam }\end{array}$ & 36 & 42 & 20 & 1 & 0 & 410 & 4,14 & Baik \\
\hline 4 & $\begin{array}{l}\text { Tersedianya berbagai macam } \\
\text { produk pelengkap dari produk } \\
\text { utama yang ditawarkan di } \\
\text { Alfamart Blahkiuh. }\end{array}$ & 37 & 38 & 24 & 0 & 0 & 409 & 4,13 & Baik \\
\hline 5 & $\begin{array}{l}\text { Alfamart Blahkiuh } \\
\text { menyediakan produk yang di } \\
\text { btuhkan oleh konsumen } \\
\text { Ketersediaan produk }\end{array}$ & 34 & 53 & 12 & 0 & 0 & 418 & 4,22 & $\begin{array}{l}\text { Sangat } \\
\text { Baik }\end{array}$ \\
\hline 6 & $\begin{array}{l}\text { Alfamart Blahkiuh sangat di } \\
\text { perhatikan }\end{array}$ & 31 & 46 & 21 & 1 & 0 & 404 & 4,08 & Baik \\
\hline 7 & $\begin{array}{l}\text { Produk yang ditawarkan } \\
\text { Alfamart Blahkiuh terdiri dari } \\
\text { berbagai macam merek }\end{array}$ & 30 & 41 & 28 & 0 & 0 & 398 & 4,02 & Baik \\
\hline 8 & Merek apapun yang dibutuhkan & 26 & 52 & 20 & 1 & 0 & 400 & 4,04 & Baik \\
\hline
\end{tabular}


konsumen selalut ersedia di

Alfamart Blahkiuh

\section{Jumlah Skor}

Rata-rata skor
$3.218 \quad 402,25$

$32,51 \quad 4,06$

Baik

Sumber : data diolah, 2020

Berdasarkan Tabel 10 dapat dilihat bahwa seluruh penilaian katagori seluruh pernyataan kuesioner termasuk dalam katagori sangat baik dengan skor rata-rata sebesar 4,25. Jawaban dengan nilai rata-rata tertinggi terdapat dalam pernyataan no 1 dengan nilai rata-rata sebesar 4,64 menyatakan bahwa Fasilitas Pelengkap yang disediakan Alfamart Blahkiuh seperti rak-rak, mejakasir, Toilet dalam keadaan baik. Sedangkan untuk nilai rata-rata jawaban terendah terdapat dalam pernyataan no 7 dengan skor rata-rata sebesar 3,69 dimana menyatakan bahwa Keramahan karyawan Alamart dalam melayani konsumen pada saat berbelanja di Alfamart Blahkiuh sudah sesuai dengan harapan. Hal ini menghindikasikan bahwa karyawan di Alfamart Blahkiuh di Badung cenderung kurang memiliki sikap yang ramah dalam melayani konsumen.

\section{Tabel 10.Kriteria dan Jawaban Penilaian Jawaban Kuesioner Variabel Kualitas Pelayanan}

\begin{tabular}{|c|c|c|c|c|c|c|c|c|c|}
\hline & \multirow{2}{*}{ Pernyataan } & \multicolumn{5}{|c|}{ Jawaban } & \multirow[t]{2}{*}{$\begin{array}{l}\text { Jumlah } \\
\text { Skor }\end{array}$} & \multirow{2}{*}{$\begin{array}{l}\text { Rata- } \\
\text { Rata } \\
\text { Skor }\end{array}$} & \multirow[t]{2}{*}{$\begin{array}{l}\text { Kategori } \\
\text { Penilaian }\end{array}$} \\
\hline & & 5 & 4 & 3 & 2 & $\mathbf{1}$ & & & \\
\hline 1 & $\begin{array}{l}\text { Fasilitas Pelengkap yang } \\
\text { disediakan Alfamart Blahkiuh } \\
\text { seperti rak-rak, mejakasir, } \\
\text { Toilet dalam keadaan baik }\end{array}$ & 68 & 26 & 5 & 0 & 0 & 459 & 4,64 & $\begin{array}{l}\text { Sangat } \\
\text { Baik }\end{array}$ \\
\hline 2 & $\begin{array}{l}\text { Karyawan Alfamart Blahkiuh } \\
\text { berpenampilan bersih dan rapi }\end{array}$ & 65 & 30 & 3 & 1 & 0 & 456 & 4,61 & $\begin{array}{l}\text { Sangat } \\
\text { baik }\end{array}$ \\
\hline 3 & $\begin{array}{l}\text { Keakuratan perhitungan } \\
\text { administrasi oleh kasir Alfamart } \\
\text { Blahkiuh pada saat pembayaran } \\
\text { barang belanjaan }\end{array}$ & 66 & 30 & 2 & 1 & 0 & 458 & 4,63 & $\begin{array}{c}\text { Sangat } \\
\text { Baik }\end{array}$ \\
\hline 4 & $\begin{array}{l}\text { Kemudahan sistem pembayaran } \\
\text { kartu kredit, Debit dan Voucher } \\
\text { yang ditawarkan Alfamart } \\
\text { Blahkiuh sesuai dengan harapan }\end{array}$ & 55 & 42 & 1 & 0 & 0 & 448 & 4,53 & $\begin{array}{l}\text { Sangat } \\
\text { Baik }\end{array}$ \\
\hline 5 & $\begin{array}{l}\text { Karyawan Alfamart Blahkiuh } \\
\text { tidak membiarkan konsumen } \\
\text { berdiri lama mengantre saat } \\
\text { pembayaran di kasir }\end{array}$ & 65 & 31 & 2 & 1 & 0 & 457 & 4,62 & $\begin{array}{l}\text { Sangat } \\
\text { Baik }\end{array}$ \\
\hline 6 & $\begin{array}{l}\text { Karyawan Alfamart Blahkiuh } \\
\text { cepat dan tanggap dalam } \\
\text { melayani kebutuhan konsumen } \\
\text { sesuai dengan harapan } \\
\text { konsumen. }\end{array}$ & 54 & 43 & 1 & 0 & 0 & 447 & 4,52 & $\begin{array}{l}\text { Sangat } \\
\text { Baik }\end{array}$ \\
\hline 7 & $\begin{array}{l}\text { Keramahan karyawan Alamart } \\
\text { dalam melayani konsumen pada } \\
\text { saat berbelanja di Alfamart } \\
\text { Blahkiuh sudah sesuai dengan } \\
\text { harapan }\end{array}$ & 12 & 45 & 41 & 1 & 0 & 365 & 3,69 & Baik \\
\hline 8 & $\begin{array}{l}\text { Karyawan Alfamart Blahkiuh } \\
\text { mengetahui produk - produk } \\
\text { yang di butkuhkan konsumen }\end{array}$ & 11 & 50 & 37 & 1 & 0 & 368 & 3,72 & Baik \\
\hline 9 & $\begin{array}{lrr}\text { Karyawan } & \text { Alfamart } & \text { Blahkih } \\
\text { memiliki } & \text { kesungguhan dalam } \\
\text { merespon } & \text { permintaan } \\
\text { konsumen } & \end{array}$ & 22 & 49 & 2 & 4 & 0 & 386 & 3,90 & Baik \\
\hline 10 & $\begin{array}{l}\text { Karyawan Alfamart Blahkiuh } \\
\text { memberikan pelayanan yang }\end{array}$ & 14 & 42 & 42 & 1 & 0 & 366 & 3,70 & Baik \\
\hline
\end{tabular}


sama tanpa memandang status social

Sumber : data diolah, 2020

Jumlah Skor Rata-rata skor

$4.210 \quad 421,00 \quad$ Sangat

$42,53 \quad 4,25 \quad$ Baik

\section{Uji Asumsi Klasik}

1. Uji Normalitas

Data penelitian dikatakan menyebar normal atau memenuhi uji normalitas apabila nilai Asymp.Sig (2-tailed) variabel residual berada di atas 0,05 atau 5\%, sebaliknya jika nilai Asymp.Sig (2-tailed) variabel residual berada di bawah 0,05 atau 5\%, maka data tersebut tidak berdistribusi normal atau tidak memenuhi uji normalitas.

Tabel 11

Uji Normalitas

One-Sample Kolmogorov-Smirnov Test

\begin{tabular}{|ll|r|}
\hline & & $\begin{array}{c}\text { Unstandardized } \\
\text { Residual }\end{array}$ \\
\hline $\mathrm{N}$ & Mean & 99 \\
Normal Parameters ${ }^{\mathrm{a}, \mathrm{b}}$ & Std. Deviation & .0000000 \\
Most Extreme Differences & Absolute & 4.76814551 \\
& Positive & .108 \\
& Negative & .060 \\
Test Statistic & & -.108 \\
Asymp. Sig. (2-tailed) & & .108 \\
\hline
\end{tabular}

a. Test distribution is Normal.

b. Calculated from data.

Sumber : data diolah, 2020

Berdasarkan Tabel 11, terlihat bahwa nilai Sig.(2-tailed) sebesar 0,164 >0,05. Oleh sebab itu Ho tidak dapat ditolak. Hal itu berarti nilai residual terstandarisasi dinyatakan menyebar secara normal.

2. Uji Multikolinearitas

Multikolinearias dapat dilihat dengan Variance Inflation Factor (VIF), apabila nilai VIF < 10 dan nilai tolerance> 0,10 maka tidak terdapat gejala multikolinearitas (Ghozali, 2011:106).

Tabel 12

\section{Uji Multikolinieritas}

Coefficients $^{\mathrm{a}}$

\begin{tabular}{|l|c|c|c|c|c|}
\hline Model & $\begin{array}{c}\text { Unstandardized } \\
\text { Coefficients }\end{array}$ & $\begin{array}{c}\text { Standardized } \\
\text { Coefficients }\end{array}$ & $\mathrm{t}$ & Sig. & Collinearity Statistics \\
\hline
\end{tabular}




\begin{tabular}{|ll|r|r|r|r|r|r|}
\hline & B & Std. Error & Beta & & & Tolerance & VIF \\
\hline 1 & (Constant) & 6.110 & 5.473 & & 2.217 & .027 & \\
\\
X1
\end{tabular}

a. Dependent Variable: $Y$

Sumber : data diolah, 2020

Dengan melihat VIF (Varian Inflation Factor) variabel Lokasi (X1), Kelengkapan Produk (X2) dan Kualitas Pelayanan (X3) lebih kecil dari 10 dan Tolerance variabel Lokasi (X1), Kelengkapan Produk (X2) dan Kualitas Pelayanan (X3) lebih besar dari 0,10, maka pada model regresi yang terbentuk tidak terjadi gejala multikolinieritas.

3. Uji Heteroskedastisitas

Berdasarkan Tabel 13, diketahui bahwa pada model regresi tidak terjadi gejala heteroskesdastisitas. Hasil ini karena Sig. variabel Lokasi (X1) terdapat absolut residual sebesar 0,375 > 0,05, variabel Kelengkapan Produk (X2) terdapat absolut residual sebesar 0,897 > 0,05 dan variabel Kualitas Pelayanan (X3) terdapat absolut residual sebesar 0,827 > 0,05 maka pada model regresi yang terbentuk tidak terjadi gejala heteroskesdastisitas

Tabel 13

Hasil Uji Heteroskesdastisitas.

Coefficients $^{a}$

\begin{tabular}{|c|c|c|c|c|c|c|}
\hline \multirow{2}{*}{\multicolumn{2}{|c|}{ Model }} & \multicolumn{2}{|c|}{ Unstandardized Coefficients } & \multirow{2}{*}{$\begin{array}{c}\begin{array}{c}\text { Standardized } \\
\text { Coefficients }\end{array} \\
\text { Beta }\end{array}$} & \multirow[b]{2}{*}{$\mathrm{T}$} & \multirow[b]{2}{*}{ Sig. } \\
\hline & & B & Std. Error & & & \\
\hline \multirow[t]{4}{*}{1} & (Constant) & 7.225 & 3.368 & & 1.145 & .134 \\
\hline & $\mathrm{X} 1$ & -.059 & .066 & -.111 & -.891 & .375 \\
\hline & $\mathrm{X} 2$ & -.010 & .079 & -.016 & -.129 & .897 \\
\hline & X3 & -.018 & .081 & -.025 & -.219 & .827 \\
\hline
\end{tabular}

a. Dependent Variable: Abs_ut

Sumber : data diolah, 2020

\section{Analisis Regresi linear Berganda}

Pengujian hipotesis dilakukan untuk menguji hipotesis yang diajukan. Hipotesis yang diajukan dalam penelitian ini terkait variabel Lokasi dan Kelengkapan Produk.

Tabel 14

\section{Hasil Uji Regresi Linear Berganda}




\begin{tabular}{|c|c|c|c|c|c|c|}
\hline \multicolumn{7}{|c|}{ Coefficients $^{a}$} \\
\hline \multirow{2}{*}{\multicolumn{2}{|c|}{ Model }} & \multicolumn{2}{|c|}{ Unstandardized Coefficients } & $\begin{array}{l}\text { Standardized } \\
\text { Coefficients }\end{array}$ & \multirow[b]{2}{*}{$\mathrm{t}$} & \multirow[b]{2}{*}{ Sig. } \\
\hline & & $\mathrm{B}$ & Std. Error & Beta & & \\
\hline \multirow[t]{4}{*}{1} & (Constant) & 6.110 & 5.473 & & 2.217 & .027 \\
\hline & $\mathrm{X} 1$ & .242 & .108 & .223 & 2.516 & .019 \\
\hline & $\mathrm{X} 2$ & .365 & .128 & .291 & 3.071 & .004 \\
\hline & X3 & .767 & .132 & .496 & 5.795 & .000 \\
\hline
\end{tabular}

a. Dependent Variable: $\mathrm{Y}$

Sumber : data diolah, 2020

Berdasarkan tabel diatas dapat diketahui persamaan regresinya menjadi $Y=\alpha+\beta_{1} . X_{1}+\beta_{2} . X_{2}+\beta_{3} . X_{3}+\varepsilon i$

Dari persamaan diatas maka dapat dibuat persamaan regresi penelitian ini adalah : $\mathrm{Y}=6,110+$ $0,242 \times 1+0,365 \times 2+0,767 \times 3+\varepsilon i$

Interprestasi dari koefisien regresi :

$\alpha=6,110$ secara statistik menunjukan bahwa Keputusan Pembelian akan meningkat sebesar 6,110 persen dengan syarat variabel lain dalam penelitian ini yakni Lokasi (X1), Kelengkapan Produk (X2) dan Kualitas Pelayanan (X3) diasumsikan sama dengan nol.

$\beta 1=0,242 \quad$ secara statistik menunjukkan ada pengaruh positif antara variabel Lokasi (X1) terhadap Keputusan Pembelian (Y) sebesar 0,242 yang artinya setiap terjadi (adanya) peningkatan Lokasi sebesar satu satuan maka akan menyebabkan meningkatnya Keputusan Pembelian sebesar 0,242 dengan syarat variabel lain diasumsikan sama dengan nol.

$\beta 2=0,365 \quad$ secara statistik menunjukkan ada pengaruh positif antara variabel Kelengkapan Produk (X2) terhadap Keputusan Pembelian (Y) sebesar 0,365 yang artinya setiap terjadi kenaikan (adanya) Kelengkapan Produk sebesar satu satuan maka akan menyebabkan meningkatanya Keputusan Pembelian sebesar 0,365 dengan syarat variabel lain diasumsikan sama dengan nol.

$\beta 3=0,767 \quad$ secara statistik menunjukkan ada pengaruh positif antara variabel Kualitas Pelayanan (X3) terhadap Keputusan Pembelian (Y) sebesar 0,767 yang artinya setiap terjadi kenaikan (adanya) Kualitas Pelayanan sebesar satu satuan maka akan menyebabkan meningkatanya Keputusan Pembelian sebesar 0,767 dengan syarat variabel lain diasumsikan sama dengan nol.

\section{Analisis Koefisien Determinasi}


Berdasarkan Tabel 15, atas koefisien determinasi $\left(\mathrm{R}^{2}\right)$ yang ditunjukkan dari nilai Adjusted $R$ Square sebesar 0,722. Hal ini berarti variabel dependen Keputusan Pembelian (Y) dapat dijelaskan oleh tiga variabel independen yaitu Lokasi (X1), Kelengkapan Produk (X2) dan Kualitas Pelayanan (X3) sebesar 72,20\% sedangkan sisanya 0,278 atau 27,80\% dijelaskan oleh variabel atau sebab - sebab lainnya di luar model penelitian.

Tabel 15

Hasil Uji Analisis Koefisien Determinasi $\left(\mathbf{R}^{2}\right)$

Model Summary

\begin{tabular}{|c|c|c|c|c|}
\hline Model & $\mathrm{R}$ & R Square & $\begin{array}{l}\text { Adjusted R } \\
\text { Square }\end{array}$ & $\begin{array}{c}\text { Std. Error of the } \\
\text { Estimate }\end{array}$ \\
\hline 1 & $.963^{a}$ & .740 & .722 & 2.843 \\
\hline
\end{tabular}

a. Predictors: (Constant), X3, X2, X1

Sumber : data diolah, 2020

\section{Uji Signifikan Parsial (Uji t-Test)}

Secara persial pengujian hipotesis dilakukan dengan uji t-test. Menurut Ghozali, (2011:98). Uji statistik t pada dasarnya menunjukkan seberapa jauh pengaruh satu variabel penjelas/independen digunakan untuk menguji hipotesis $\mathrm{H} 1, \mathrm{H} 2$ dan $\mathrm{H} 3$ yaitu pengaruh secara parsial variabel Lokasi, Kelengkapan Produk dan Kualitas Pelayanan terhadap Keputusan Pembelian. Berdasarkan Tabel 14 maka dapat dikemuakan hasil uji t-Test adalah sebagai berikut

1. Pengaruh Lokasi Terhadap Keputusan Pembelian pada Alfamart Blahkiuh di Kabupaten Badung. Blahkiuh di Kabupaten Badung

Dari hasil penelitian diketahui adanya pengaruh positif dan signifikan Lokasi terhadap Keputusan Pembelian. Hal ini dibuktikan dengan nilai $\beta 1=0,242$ serta $t_{\text {hitung }}(2,516)>t_{\text {tabel }}$ $(1,658)$, dan sig. 0,019 < 0,05 maka H1 diterima. Ini berarti bahwa secara statistik Lokasi (X1) berpengaruh signifikan terhadap Keputusan Pembelian (Y). Artinya jika terjadi peningkatan Lokasi (X1) akan meningkatkan Keputusan Pembelian (Y).

2. Pengaruh Kelengkapan Produk terhadap Keputusan Pembelian pada Alfamart Blahkiuh di Kabupaten Badung

Dari hasil penelitian diketahui adanya pengaruh positif dan signifikan Kelengkapan Produk terhadap Keputusan Pembelian. Hal ini dibuktikan dengan nilai $\beta 2=0,365$ serta $t_{\text {hitung }}$ $(3,071)>t_{\text {tabel }}=1,658$ dan sig. $0,004<0,05$ maka $\mathrm{H} 2$ diterima. Ini berarti bahwa secara statistik Kelengkapan Produk (X2) berpengaruh signifikan terhadap Keputusan Pembelian 
(Y). Artinya jika terjadi peningkatan Kelengkapan Produk (X2) akan meningkatkan Keputusan Pembelian (Y).

3. Pengaruh Kualitas Pelayanan Terhadap Keputusan Pembelian pada Alfamart Blahkiuh di Kabupaten Badung

Dari hasil penelitian diketahui adanya pengaruh positif dan signifikan Kualitas Pelayanan terhadap Keputusan Pembelian. Hal ini dibuktikan dengan nilai $\beta 3=0,767$ serta $t_{\text {hitung }}(5,795)$ $>t_{\text {tabel }}(1,658)$ dan sig. $0,000<0,05$ maka H3 diterima. Ini berarti bahwa secara statistik Kualitas Pelayanan (X3) berpengaruh signifikan terhadap Keputusan Pembelian (Y). Artinya jika terjadi peningkatan Kualitas Pelayanan (X3)) akan meningkatkan Keputusan Pembelian (Y).

\section{Uji Signifikansi Simultan (F-Test)}

Uji statistik f pada dasarnya menunjukkan apakah semua variabel independen atau bebas yang dimasukkan dalam model mempunyai pengaruh secara bersama - sama terhadap variabel dependen/terikat. Uji f-test digunakan untuk menguji H4, yaitu pengaruh Lokasi (X1) Kelengkapan Produk (X2) dan Kualitas Pelayanan (X3) secara simultan berpengaruh terhadap Keputusan Pembelian (Y).

\section{Tabel 16}

\section{Hasil Uji Signifikan Simultan (Uji F-Test)}

ANOVA $^{\mathrm{a}}$

\begin{tabular}{|ll|r|r|r|r|r|}
\hline \multicolumn{1}{|c|}{ Model } & Sum of Squares & Df & Mean Square & F & Sig. \\
\hline 1 & Regression & 1750.677 & 3 & 583.559 & 24.882 & .000 \\
Residual & 2228.051 & 95 & 23.453 & & \\
Total & 3978.727 & 98 & & & \\
\hline
\end{tabular}

a. Dependent Variable: $Y$

Sumber : data diolah, 2020

Hasil uji menunjukkan bahwa variabel independen yang terdiri Lokasi, Kelengkapan Produk dan Kualitas Pelayanan berpengaruh terhadap Keputusan Pembelian. Hal ini dibuktikan dengan nilai $F_{\text {tabel }}(2,68)<F_{\text {hitung }}(24,882)$ dan sig. $0,000<0,005$, maka $\mathrm{H} 4$ diterima. Ini berarti bahwa dan kualitas pelayanan berpengaruh positif dan signifikan terhadap keputusan pembelian. Dengan demikian hipotesis yang menyatakan bahwa dan kualitas pelayanan berpengaruh positif dan signifikan terhadap Keputusan Pembelian teruji kebenarannya.

\section{Simpulan}

Berdasarkan data yang diperoleh dari hasil analisis dapat ditarik kesimpulan sebagai berikut 
1. Lokasi berpengaruh positif dan signifikan terhadap Keputusan Pembelian pada Alfamart Blahkiuh di Badung. Kelengkapan Produk berpengaruh positif dan signifikan terhadap Keputusan Pembelian pada Alfamart Blahkiuh di Badung.

2. Kualitas Pelayanan berpengaruh positif dan signifikan terhadap Keputusan Pembelian pada Alfamart Blahkiuh di Badung.

3. Lokasi, Kelengkapan Produk dan Kualitas Pelayanan berpengaruh positif dan signifikan terhadap Keputusan Pembelian pada Alfamart Blahkiuh di Badung.

\section{Saran}

1. Berdasarkan hasil penelitian,nilai rata-rata jawaban terendah pada vaiabel lokasi dengan nilai rata-rata sebesar 3,96 dimana menyatakan bahwa Alfamart Blahkiuh mudah dijangkau berbagai transportasi. Maka diharapkan kepada manajemen Alfamart dalam mendirikan kantor cabang baru sebaiknya melakukan analisis lokasi lebih baik sehingga dapat meningkatkan keputusan pembelian konsumen karena memenuhi syarat lokasi strategis.

2. Diharapkan manajemen Alfamart Blahkiuh di Badung menambah varian produk yang dipasarkan untuk meningkatkan keputusan pembelian konsumen karena berdasarkan hasil nilai rata-rata jawaban terendah pada variabel kelengkapan produk dengan nilai rata-rata sebesar 3,85 dimana menyatakan bahwa Keragaman produk yang ditawarkan Alfamart Blahkiuh memiliki ciri khas sendiri dibanding Toko retail lain.

3. Diharapkan, manajemen Alfamart Blahkiuh di Kabupaten Badung mengarahkan karyawannya untuk bersifat ramah kepada seluruh konsumen dengan cara melayani kebutuhan konsumen pertanyaan atau selalu memberikan senyum kepada konsumen yang datang berbelanja karena nilai rata-rata jawaban terendah pada variabel kualitas pelayanan dengan skor rata-rata sebesar 3,69 dimana menyatakan bahwa Keramahan karyawan Alamart dalam melayani konsumen pada saat berbelanja di Alfamart Blahkiuh sudah sesuai dengan harapan.

4. Bagi peneliti selanjutnya dengan berbagai keterbatasan penelitian ini, diharapkan lebih mendalam mengkaji perihal pengaruh Lokasi, Kelengkapan Produk dan Kualitas Pelayanan terhadap Keputusan Pembelian agar hasilnya lebih akurat. Selain itu, peneliti selanjutnya juga diharapkan untuk mengkaji variabel-variabel lain mengingat koefisien determinasi yang dihasilkan sebesar $72,20 \%$ sedangkan $27,80 \%$ terdapat variabel lain yang tidak termasuk dalam model penelitian yang kemungkinan berpengaruh terhadap Keputusan Pembelian contohnya variabel Promosi, Citra Merek, Harga, dll

\section{DAFTAR PUSTAKA}


Ananda, Rusydi dan Tien Rafida, 2016. Pengantar Kewirausahaan. Medan: Perdana Publishing.

Basu Swastha. 2012. Manajemen Pemasaran : Analisis dan Perilaku Konsumen.

Budianto. 2015. Manajemen Pemasaran Pendekatan Praktis. Yogyakarta: Ombak (Anggota

IKAPI). Drs. FX Budiyanto) , Jakarta: Binarupa Aksara

Engel , James F, et al, 2012. Perilaku Konsumen Edisi 6 Jilid 2 ( Alih Bahasa:

Fandy Tjiptono, Strategi Pemasaran, Edisi kedua (Yogyakarta : Andi, 2007), h. 92.

Fure. 2013. "Analisis Pengaruh Kualitas Pelayanan Terhadap Keputusan Konsumen Menggunakan pada Pt Sedana Yasa”. Skripsi Dipublikasikan UniversitasDiponegoro Semarang.

Ghozali, I. 2011. Analisis Multivariate Dengan Program SPSS" Semarang. Badan Penerbit Universitas diponegoro

Gilbert. 2003. Retail Marketing Management. New Jersey: Prentice Hall.

Hakim M. M. D. 2016. Pengaruh kualitas layanan, harga, lokasi dan promosi terhadap keputusan pembelian. Jurnal Ilmu dan Riset Manajemen : Volume 5, Nomor 11, November 2016.https://ejournal.stiesia.ac.id/jirm/article/download/2668/2378. Diakses pada 25 januari 2018

Keputusan PembelianPada Mini Market Alfamart. Jurnal EMBA Vol.1 ISSN 23011174.

Kotler, P \& K.L. Amstrong. 2008. Prinsip-prinsip Pemasaran. Jilid 1 Dan 2.Edisi 12.Jakarta: Erlangga.

Kotler. 2007. Dasar-Dasar Manajemen. Edisi Kesembilan. PT. Indeks. Jakarta.

Parasuraman, A., V.A. Zeithmal., dan L.L. Berry. 1988. SERVQUAL : A Multiplie Item Scale for Measuring Consumer Perception of Service Quality. Journal of Retailing,

Peter dan Olson, 2012. Pengaruh Kelengkapan Produk dan Pelayanan terhadap

Utami. 2010. Kelengkapan Produk Suatu Perusahaan. Penerbit PT. Indeks Kelompok Gramedia, Jakarta.

Winardi, 2010 Pengaruh Kelengkapan Produk da Lokasi Usaha Terhadap

KeputusanPembelian (Studi Pada Konsumen Metor Pasar Swalayan Medan).

Winardi, 2010. Keputusan Pembelian Suatu Perusahaan. Penerbit PT. Indeks Kelompok Gramedia, Jakarta.

Lupiyadi \& Hamdani. 2008. Manajemen Pemasaran Jasa. Salemba Empat. Jakarta.

Lamb, Charles. 2011. Pemasaran Edisi Pertama. Jakarta: Salemba Empat.

Malau, Harman. 2017 Manajemen Pemasaran. Bandung: Alfabeta.

Martono, Nanang, 2012. Metode Penelitian Kuantitatif. Jakarta: Rajawali Pers.

Munawaroh, Munjiati, 2016. dkk. Kewirausahaan Untuk Program Strata 1. Yogyakarta: LP3M UMY.

Marnis. 2008. Manajemen Jasa. Edisi Kesembilan. PT. Indeks. Jakarta.

Mulyani. 2009. Analisis Faktor-Faktor yang Mempengaruhi Loyalitas Pelanggan

Pasar Swalayan denganKepuasan Sebagai Variabel Intervening (Studi Kasus Pada Pasar Swalayan Luwes di Purwodadi).Excellent Vol. 1 No. 2.

Musfiqum. 2010. Metode Penelitian Pendidikan Pendekatan Kuantitatif, kualitatif, dan R\&D. Bandung:Alfabeta.

Moenir. 2005. Manajemen Pelayanan Umum di Indonesia. Bumi Aksara, Jakarta.

Nawari, Analisis Regresi dengan MS. Excel 2007 san SPSS 17. Jakarta: PT. Elex Media Komputido. 2010.

Prianto, Duwi. SPSS untuk Analisis Korelasi, Regresi, Multivariante. Yogyakarta: Guva Media. 2009. 